\title{
PERSONAL NAMES AMONG SOME WEST AFRICAN TRIBES
}

To Europeans accustomed to all the complexities of civilisation names seem to fill rather an important part in daily life, and cannot conveniently be dispensed with. In a primitive society, however, and in small village communities such as African negroes live in with few exceptions, their necessity is very much smaller. Socialistic life with its general equality of all persons rather discountenances prominence of the individual. Hence there is a general tendency to use such terms as "my friend," and not to use the name of the person addressed. Holding on to one's name as a sacred possession to be proud of is rare, so small is the chance of personal distinction. Hence adoption of new names to obscure identity, especially when starting a new career which takes the individual away from his own village, is almost universal. In this connection, it must be noticed that the assumption of a string of lengthy English names by imperfectly trained scholars of the rising generation is a very common practice, and is an indication of a state of megalomania that has little to justify it.

A single name is almost invariably considered sufficient for an individual until he goes abraad in the world. This, of course, is parallel to the personal name alone being used in families in Europe, for in the native villages nearly everybody is related, except to such as in the former days might come in : they might be refugees from elsewhere who asked permission to settle in the village, or they might be slaves introduced as the result of a successful war.

The primary right to name rests with the mother, whether the offspring be a male or a female. This is due to the fact that the father in wild communities holds only a secondary position as regards the offspring, his identity being often uncertain. The name given by the mother may or may not 
be retained in after-life. It depends on circumstances or tribal custom, as will be explained below.

Here I may state as a caution that I have had no opportunity to prosecute my researches very widely amongst the multitude of tribes in West Africa. My observations are based on comparatively few of them, but there is some compensation in the fact that they are representative of areas placed somewhat widely apart.

In all tribes there are, I think, certain rules or customs as to the giving of names which act as a general guide, though they may be overruled by the personal inclination of the mother. How far this is permitted, however, would vary considerably according to the situation of the tribe as regards its communications with the outside world. For instance, when the parents are of different tribes a name belonging to each may be selected, that of the mother's tribe standing first. Religion also, i.e., Christianity or Mohammedanism, has been and still is a potent influence in the naming of the child, if not as regards its original name, which is less usual, certainly as regards its later name.

I will now deal with a few selected tribes, giving examples of naming being governed by rules. Amongst the Twi speak. ing tribes, which are found in the Gold Coast calony and in the French Ivory Coast colony, and also amongst the Efe tribes which lie to the eastward in Togoland and the French colony of Dahomey, unlike the majority of tribes in West Africa, the days of the week bear names, the week being one of seven days, and boys and girls are named according to the day they are born on. This system has been borrowed by the $\mathrm{Ga}$ speaking tribes, Accra, Krobo and Adangme, from Twi, and its origin in Efe is due to the same source.

The list of names in Twi is as follows, differing slightly in the various dialects:

\begin{tabular}{ll}
\multicolumn{2}{c}{ Day of Week. } \\
Sunday & Krasida \\
Monday & Droda \\
Tuesday & Benada \\
Wednesday & Wuknda \\
Thursday & Yawda \\
Friday & Fide \\
Suturday & Memeneda
\end{tabular}

Twi.

$\begin{array}{ll}\text { Male Name. } & \text { Fomale Name. } \\ \text { Kwasi } & \text { Akoswa, Akwasibe } \\ \text { Kwadwo } & \text { Adwowa } \\ \text { Kwabena } & \text { Abena } \\ \text { Kwaku } & \text { Akun } \\ \text { Yar } & \text { Ya, Yawa } \\ \text { Kof } & \text { Afoin } \\ \text { Kwame } & \text { Amma }\end{array}$


FANTI.

Day of Wak.1

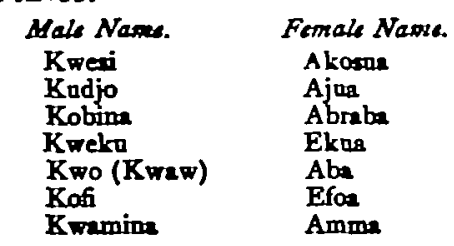

Names are also given according to the number of children born, and are frequently duplicated with the namedays:

Male Name.

Menon

Aneng

Asong and Botwe

Akrong

Bada

Ata.

Tavis

Famale Name
Manse
Maneng
same
Nkromme
Baduwa
Ata, Atars
Tawie

third child

fourth child

seventh and eighth child

ninth child

tenth child

a twin

child born after twin

In combination the name day always stands first, as $\mathrm{Kwesi}$ Mensa, Kwami, Tawia.

There are besides these a great number of other names that are used, but the foregoing are those most commonly met with.

The names in Efe are slightly different. The following is a list of the days of the week with the names derived therefrom :
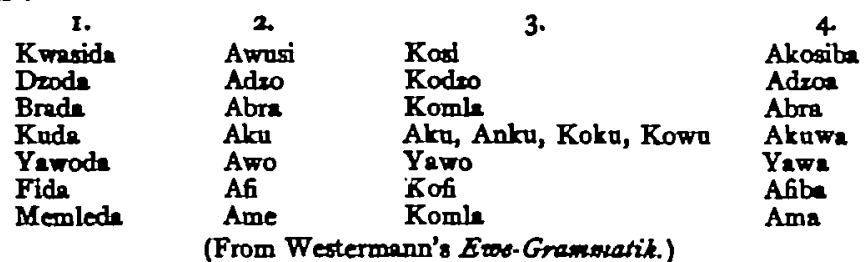

The first list is that of the days of the week. The second is common names, male and female, used for greeting. The greeter calls to the greeted in the name of his own (greeter's) birthday, and the reply is similar. List No. 3 is men's names, and No. 4, women's names.

The foregoing, of course, by no means exhaust the list of Efe names. They are exceedingly numerous and quite different from the bulk of Twi names. In fact it seems to be only naming from days of the week that has been borrowed from Twi.

Passing on, now, to the colony of Sierra Leone : among $\checkmark$ See previous page, ander TwI. 
the Mende the system is quite different. A child is named at birth by its mother, and the number of possible names is very great, running probably to some hundreds. When the boy goes to the Poro-bush to be educated he is given his' new name, called his Poro name, as opposed to his birth name (in Mende Poro-biye; Le-biye). The name taken is usually the same as that of a near relative. The names are frequently Mohammedan names corrupted, as Ali ; Boima or Braima for Ibrahima; Musa; Momo for Mohammed; Sumana for Othman, etc. For women Hawa is found. On the other hand, mothers sometimes give their babies the English name Joe, which is rather popular.

The derivation of Mende names is not easily arrived at, but a few seem to be the names of animals slightly corrupted. However, the bearers of those names never, so far as my observation goes, seem aware that they are named after an animal. The number is not great. As specimens may be mentioned Hoke (Hooki), which means a guinea fowl, and Kaikula or Kaikura which may be akin to Kaikulo (definite form-Kaikuli), meaning a kind of ground squirrel. An objection to this derivation as regards the latter is that in the personal name the "ai" is short, whereas in the name of the animal it is long.

For women there is the name of Titi. Now "titi" is the red flower of one species of silk-cotton tree (Bombax sp.), but whether it is the same word I am by no means sure. Yenge, work, is also a woman's name.

Other names with distinct meanings are Navo, money; Hindolo, male-child; Mboma, a net. The addition of the name Laga means that the bearer of the name has acquired a certain distinction in the Porabush. I only know two men bearing that name, and they had both been educated in the Temne Poro-bush instead of in the Mende Poro-bush.

Names are given in Mende to indicate some physical pecu. liarity. A "red" man, that is a light complexioned individual, is commonly called Gboli (Gborli). A man with a black complexion, the general colour being dark-brown, is Bundu. Borbor is a favourite name for babies, which is often retained. It means practically "baby," and the same name is found in 
the Fula language with the same meaning. Other names of a similar nature are Bagule and Kabagule for reddish men, while reddish women may be called Mamagule, Jengo, and Segbe. A man with a stiff or thick neck gets the name Kunbulume. Short men may be called Gendeme, Tumbui, and tall men, Pajonga and Moivumba. Amongst long names, which are really nicknames, are Kwengba-bolowa and Jogendakokovakai. Their meaning I do not know, except that "bolowa" means long neck. If two men bear the same name, for instance if each is called Mbaio, one will not call out to the other using that name, but each will call the other Toma, meaning "name-sake." This word is also found in Mandingo.

Many names of men in Mende have " $\mathrm{Ka}$ " or " $\mathrm{Kai}$ " as a prefix, as Kabanga, Kapindi, Kailundu, Kaiyenge, Kaitibi. With women " $\mathrm{Ma}$ " is found, as Mafende, Mahenda, Manje.

Mende being classifiable as a Mandingo dialect, it is only to be expected that many Mende names should also be used amongst kindred tribes. Similar names are, however, also met with in neighbouring tribes with totally distinct languages, but may possibly only be used where the two tribes are contiguous. For instance Bai, a Temne name, is occasionally met with in Mende, as also is Kpana, or Gbana, a Sherbro (i.e. Bulom) name, which itself is also used by the Temne. Lahai and Kali are two other names that are found in both Mende and Temne. Foday is found among Temne as well as various tribes of Mandingo origin as Mende and Vai. Sori, a Temne name, and Yamba, which I think is Temne also, are also frequently borne by Mende men.

It is curious that in Mende a few names, such as Bendu and Lombe, are borne by both men and women, and I think this is not peculiar to that language.

In Temne there is a system of clans, which number some twenty or more. Certain clan names are most frequently met with out of the country, which perhaps indicates that these clans are the largest. Amongst the commonest are Kamara, Bangura, Kano, Sesi. All these clan names are used like surnames in Europe, and so one meets men called Momo Kamara, Foday Bangura, Bai Kano, Seidu Sisi, etc. 
In Temne, also, according to Schlenker (Temne grammar, 1864, by Rev. C. F. Schlenker) patronymics for males are sometimes formed by placing the mother's name before that of the son, as Fatima Braima, Braima son of Fatima; Namina Lai, Lai the son of Namina, or by placing the word "son" after the mother's name, as Kali Modu, son of Kali ; Sere Modu, son of Sere.

Among the Vai it is not uncommon for a man to have three names. The first name given the child is always pure Vai. When he goes to the Beri-bush, the equivalent of the Mende Poro-bush, he receives his Poro name. When he becomes a Mohammedan, which most of the Vai are, his Arabic name is given him, and these three are combined in the order of Mohammedan first, Beri second, and birth name third. The inventor of the Vai syllabary bore the names, Momoru Doaru Bukere, the last name meaning "gun-war," i.e. a war in which guns were used. This is the explanation given by Koelle in his Vai Grammar, 1854, and a Vai named Chiakongo confirmed this to me about ten years ago. Another Vai known to Koelle bore the name Momoru Doaru Wonye, Wonye meaning a large kind of ant, possibly the great stink ant. He himself told Koelle the origin of the name. His mother had several children before him, all of whom died. When he was born, people said to his mother "You must give a bad name to this one, else he will die also." Hence she called him "Wonye," and he lived.

Other names of Vai men are Momoru Fa Kondo, Kondo meaning Flying Fox; Momoru Kari Kai, Kari Kai meaning Serpent Man in Mandingo; Siafa Fama Johnny; Buraima Bai Zina, Zina being a twin. A woman's name is Goanya Dsoe, Dsoe being a night bird.

Turning, now, to the tribes which are almost purely Mohammedan in religion, such as Mandingo, Fula, Hausa, etc., Arabic names are largely the rule. Still the old indigenous ones have not been entirely supplanted. In Hausa are found the following which are worth noting. Here, also, a special name attaches to a red man, who is called Jatto. Other names with meanings are Bawa, slave; Dogo, long; Gado, given to the child born after twins; Shekarao, a child a year in the 
womb (?); Tanko, first son after daughters; Dan-karo, a child begged from God. Women's names with meanings are: Ayashe, throw away; Bermani, leave me (this one); Kandi, first daughter born after sons; Koshi, satisfaction; Tarana, born in daytime; Taroro, born in bean picking season; Tagudu, born in retreat in war; and Auta, last born, male or female. The prefix "ta," it may be noted, is the genitive form of the preposition "of."

It is also common among Hausa men, who are great travellers, to add the name of their country with a prefix after their personal name, as Sidi Bakano or Sidi Dan Kano, "Ba" having rather the significance of inhabitant, and "Da-n," son of.

I have already mentioned that Arabic names are frequently taken in preference to indigenous names. European names are similarly assumed in the coast towns by natives in contact with Europeans. This is especially done at the time when a small boy goes to school. He then selects a surname with initials. The initials are taken first as a rule, and are expanded into names when the necessity arises, as when the pupil subsequently enters the Government service when a record of his service has to be started. The surname is annexed at random, and brothers will take different names. There are a few old established families in the Gold Coast that pass on the surname, but it by no means follows as a rule that because the same surname is borne there is any family relationship. Descent through the female line tends to hinder the transmission of surnames. Among the Accra people, however, where with closely related tribes of Krobo and Adangme (I believe in the latter also) descent in the male line exists, surnames have a greater value. Some are of Portuguese origin, as Ribeiro. Another big family is that of Papafio. Half caste families both among the Accras and also among the Fantis prefer to keep the name of the European ancestor, for with them property, if there be any, goes as far as local conditions will permit to the sons.

Amongst other instances of change of name may be noted that of natives of the less civilised tribes who leave their homes to work for Europeans. If they do not take Arabic 
names, they adopt some simple Christian name, as Joe, Johnny, Tommy. Others are more elaborate, as Blackman Trouble, Fineboy, Anyway, Bestman. The reason is that Europeans usually cannot manage some of the more unpronounceable native names, besides of course the reason given above of a desire to assume a new identity. Occasionally a man will take a new name in such a hurry that he has forgotten it an hour or so later.

There are several peculiarities noticeable among the takers of new names. For instance Temnes from Sierra Leone going to work abroad will generally keep to their own name, whether Mohammedan or not; Susus the same also. Mendes on the other hand will largely take European names, single names mostly, or the names of places abroad they may have been to, as Liverpool, Congo boy, and preference is given to those they can themselves pronounce most readily. Charles is used and commonly corrupted to Sass; but Charlie remains distinct. A few others used by them are Blackie, James or Jamesee; Poor-no-friend; Money-palaver; Smallboy; Saspo $=$ Chassepot. For the most part these names are reasonable ones and not far fetched. On the other hand, Kroomen largely go out of their way to find striking names. With them are found such as Two-copper; Ginbottle; Seabreeze; as well of course as the simpler christian names.

A change of name has its origin in other things than the mere desire to have a name intelligible to Europeans. There is a sort of feeling that a new name may bring better luck if the individual has not been too fortunate hitherto. He takes up new work under new auspices.

Another custom, not confined to West Africa of course, is that of chiefs when succeeding taking a new name. The Ashanti kings usually bore two names, their reigning names and their so-called "strong " name, and were sometimes better known by the latter. Opoku I. (173I-42) bore the strong name Wari; Kwesi (1742-52) Bodom; Kwamina (17811797) Penin; Opuku П. (1797-99) Fofie; and, coming down to the last, Kwaku Dua III. (1888-96) that of Ajeman Prempe.

F. W. H. MIGEOD. 